\title{
DAMPAK PEMBANGUNAN HUTAN TANAMAN INDUSTRI Acacia crassicarpa DI LAHAN GAMBUT TERHADAP TINGKAT KEMATANGAN DAN LAJU PENURUNAN PERMUKAAN TANAH (The Impact of Development of Industrial Plantation Forest Acacia crassicarpa in Peatland Towards the Maturity Level and Subsidence Rate)
}

\author{
Yunita Lisnawati $^{1^{*}}$, Haryono Suprijo ${ }^{2}$, Erny Poedjirahajoe ${ }^{2}$ dan Musyafa $^{2}$ \\ ${ }^{1}$ Pusat Penelitian dan Pengembangan Peningkatan Produktivitas Hutan, \\ Jl. Gunung Batu 5, Bogor 16610 \\ ${ }^{2}$ Fakultas Kehutanan, Universitas Gadjah Mada, Jl. Agro, Bulaksumur, Yogyakarta 55281
}

*Penulis korespondensi. Tel 0251-8631238. Fax. 0251-7520005. Email: salvinia_nita@yahoo.co.id.

Diterima: 28 November 2014

Disetujui: 11 Mei 2015

\begin{abstract}
Abstrak
Pembangunan hutan tanaman di lahan gambut tidak terlepas dari sorotan isu negatif lingkungan terkait dengan penurunan kedalaman muka air tanah, sehingga terjadi perubahan ekosistem asli. Kegiatan reklamasi lahan untuk HTI Acacia crassicarpa dalam jangka panjang disinyalir akan menimbulkan dampak negatif terhadap perubahan karakteristik tanah gambutnya seperti tingkat kematangan dan laju penurunan permukaan tanah gambut (subsiden). Kajian mengenai dampak pembangunan HTI di lahan gambut terhadap tingkat kematangan dan laju subsiden perlu dilakukan untuk memberikan informasi mengenai kondisi exsisting daya dukung lahannya. Penelitian ini bertujuan untuk mengevaluasi tingkat kematangan gambut baik secara vertikal (berdasarkan kedalaman gambut) maupun secara horizontal (berdasarkan jarak dari bibir kanal) dan mengetahui laju subsiden sebagai dampak dari reklamasi lahan gambut menjadi HTI A. crassicarpa. Penelitian dilakukan di PT AA, Distrik Rasau Kuning, Kabupaten Siak, Riau. Plot penelitian ditempatkan dalam satu transek sepanjang $100 \mathrm{~m}$ yang dibuat tegak lurus dengan kanal tersier, terdapat 12 plot dan dalam satu transek terdapat 3 titik pengamatan sehingga total titik pengamatan adalah 36 titik. Parameter yang diamati adalah dinamika kedalaman muka air tanah, nilai kadar serat tanah gambut dan laju subsiden. Hasil penelitian menunjukkan bahwa dampak perubahan kedalaman muka air tanah gambut di lokasi penelitian hanya mempengaruhi tingkat kematangan gambut pada kedalaman kurang dari 2 m, sedangkan jarak kanal tersier sebesar 125 m tidak berpengaruh secara nyata terhadap tingkat kematangan gambut. Pada kedalaman kurang dari 2 m tingkat kematangan gambut lebih tinggi dibandingkan dengan lapisan di bawahnya. Pembangunan HTI A. crassicarpa di lokasi penelitian menyebabkan laju subsiden sebesar rata-rata $5,5 \mathrm{~cm} / \mathrm{tahun}$.
\end{abstract}

Kata kunci: hutan tanaman industri, kematangan gambut, lahan gambut, laju subsiden

\begin{abstract}
The establishment of forest on peat areas is insepatable from the glare of the negative environmental issues associated with a decrease in the depth of water table which then result in a change of the original ecosystem. Longterm land reclamation activities for HTI Acacia crassicarpa is supposed to give a negative impact on changes in the peat soil characteristics such as level of maturity and the rate of decrease in surface peat soil (subsidence). Studies on the impact of HTI development in peat areas particularly on the level of maturity and rate of subsidence need to be done in order to provide information regarding the carrying capacity of the land exsisting condition. This study aims at evaluating the maturity level of the peat either vertically (based on the depth of peat) or horizontally (based on the distance from the lips of the canal) and determining the rate of subsidence as a result of reclamation of peatlands into plantations A. crassicarpa. The study was conducted in PT. AA, Rasau Kuning District, Siak, Riau. Research plots were placed in a $100 \mathrm{~m}$ long transects that were perpendicular to the tertiary canal. There are 12 plots and, transects consist of 3 observation points, so the total observation point is 36 points. Parameters measured were the dynamics of groundwater depth, the value of peat fiber content and the rate of subsidence. The results show that the impact of changes in the water table depth of peat soil in the study area only affects the level of maturity of peat at depths less than $2 \mathrm{~m}$, whereas the tertiary canals distance of $125 \mathrm{~m}$ did not significantly affect the level of maturity of peat. At a depth of less than $2 \mathrm{~m}$ of peat maturity level is higher than the layer below it. A. crassicarpa plantation development in the study area leads to subsidence rate by an average of $5.5 \mathrm{~cm} /$ year
\end{abstract}

Keywords: industrial plantation forest, peat maturity, peatland, subsidence rate

\section{PENDAHULUAN}

Peran lahan gambut sebagai penyangga lingkungan sangat penting sehubungan dengan kemampuannya dalam menyerap air dan potensinya sebagai penyimpan karbon. Selain mempunyai fungsi penting tersebut, lahan gambut juga 
mempunyai peran penting dalam pembangunan nasional dan ekonomi lokal. Disisi lain, lahan gambut merupakan lahan marginal untuk dibudidayakan dengan beberapa faktor pembatas seperti kesuburannya yang rendah, $\mathrm{pH}$ sangat masam, dan keadaan drainasenya yang jelek serta dengan faktor pembatas utama berupa kondisi media perakaran tanaman yang kurang kondusif bagi perkembangan perakaran. Akan tetapi karena keterbatasan lahan bertanah mineral, maka ekstensifikasi pertanian dalam arti luas (pertanian, perkebunan dan kehutanan) ke lahan gambut tidak dapat dihindari mengingat potensinya yang cukup luas.

Potensi lahan gambut di Indonesia diperkirakan 20,6 juta hektar atau sekitar 10,8\% dari luas daratan Indonesia (Wahyunto dkk, 2005). Data terakhir dari Peta Indikatif Penundaan Pemberian Izin Baru pada Hutan Primer dan Gambut menyebutkan angka 14,9 juta Ha. Di Indonesia pemanfaatannya telah dimulai sekitar tahun 1960-an sebagai lahan pertanian untuk program transmigrasi (Rahmadi, 2009; Saefudin, 2009). Pemanfaatan lahan gambut untuk pengembangan tanaman HTI mulai berkembang pada tahun 1990-an (Marolop dkk, 2007). Jenis Acacia crassicarpa merupakan jenis eksotik dan banyak dikembangkan sebagai tanaman pokok untuk lahan gambut di beberapa HTI-Pulp di Sumatera. Sebagai bahan baku pulp, Acacia crassicarpa termasuk jenis tanaman dengan pertumbuhan yang cepat (fast growing) dan mempunyai kualitas pulp yang baik serta sebanding dengan eukaliptus.

Pemanfaatan lahan gambut untuk HTI A. crassicarpa selalu diawali dengan pembuatan saluran drainase atau kanal untuk meningkatkan ketersediaan oksigen bagi akar supaya tanaman dapat tumbuh dan berkembang dengan baik (Hooijer dkk., 2006). Sebaliknya, pembangunan hutan tanaman di lahan gambut tidak terlepas dari sorotan isu negatif lingkungan terkait dengan penurunan kedalaman muka air tanah, sehingga terjadi perubahan ekosistem asli. Kegiatan reklamasi lahan untuk HTI A. crassicarpa dalam jangka panjang disinyalir akan menimbulkan dampak negatif terhadap perubahan karakteristik tanah gambutnya seperti tingkat kematangan dan laju penurunan permukaan tanah gambut (subsiden).

Beberapa penelitian mengenai dampak dari penurunan muka air tanah gambut sudah pernah dilakukan seperti penelitian subsidensi setelah pemanenan di lahan rawa gambut yang dilakukan oleh Suhartana dan Yuniati (2010); Suhartana dkk $\left(2013^{\mathrm{a}}\right)$; Suhartana dkk (2013 $)$ dan Suhartana dkk (2014), kemudian penelitian laju subsiden dan kehilangan karbon yang dilakukan oleh Hooijer dkk (2012). Penelitian ini mengkaji dampak pembangunan HTI di lahan gambut terhadap tingkat kematangan dan laju subsiden yang perlu dilakukan untuk memberikan informasi mengenai kondisi exsisting daya dukung lahannya. Yang membedakan penelitian ini dengan penelitianpenelitian sebelumnya adalah bahwa dalam penelitian ini bertujuan untuk mengevaluasi tingkat kematangan gambut baik secara vertikal (berdasarkan kedalaman gambut) maupun secara horizontal (berdasarkan jarak dari bibir kanal) dan mengetahui laju subsiden sebagai dampak dari reklamasi lahan gambut menjadi HTI $A$. crassicarpa.

\section{METODE PENELITIAN}

\section{Waktu dan Lokasi}

Penelitian dilaksanakan di areal HTI PT. AA, Distrik Rasau Kuning, Kabupaten Siak, Propinsi Riau. Sebagai data pembanding penelitian dilakukan di Kawasan Suaka Margasatwa Danau Pulau Besar/Danau Pulau Bawah, Kabupaten Siak, Riau. Penelitian dilakukan dari bulan Juli 2012 sampai dengan Mei 2013. Plot penelitian ditempatkan pada petak-petak tegakan $A$. crassicarpa rotasi 3 umur 1, 2, 3 dan 4 tahun.

\section{Prosedur}

Penentuan plot penelitian menggunakan metode purposive sampling (penentuan plot penelitian secara sengaja yang dianggap representatif). Titik-titik pengamatan pada masingmasing plot penelitian ditempatkan dalam satu transek sepanjang $100 \mathrm{~m}$ yang dibuat tegak lurus dengan kanal tersier. Titik-titik pengamatan tersebut pertama ditempatkan 20 m dari bibir kanal, kemudian titik berikut berjarak $50 \mathrm{~m}$, sehingga dalam satu transek terdapat 3 titik pengamatan atau pengambilan sampel tanah yang dapat mewakili jarak dari saluran drainase. Penempatan titik-titik pengamatan pada masing-masing plot penelitian dalam jalur transek disajikan pada Gambar 1.

Jalur transek penelitian diletakkan pada 12 lokasi petak kerja di PT. AA, sehingga total titik pengamatan adalah 36 titik. Parameter yang diamati adalah tingkat kematangan tanah gambut, dinamika kedalaman muka air tanah dengan menggunakan Piezometer, serta laju subsiden. Tingkat kematangan gambut dilihat dari nilai kadar serat gambut yang ditentukan di laboratorium dengan menggunakan metode pengayakan (Anonim, 2009). Pengamatan laju subsidence tidak dilakukan pengukuran langsung namun hanya melalui rumus pendekatan yang telah dilakukan oleh Hooijer dkk (2012). 


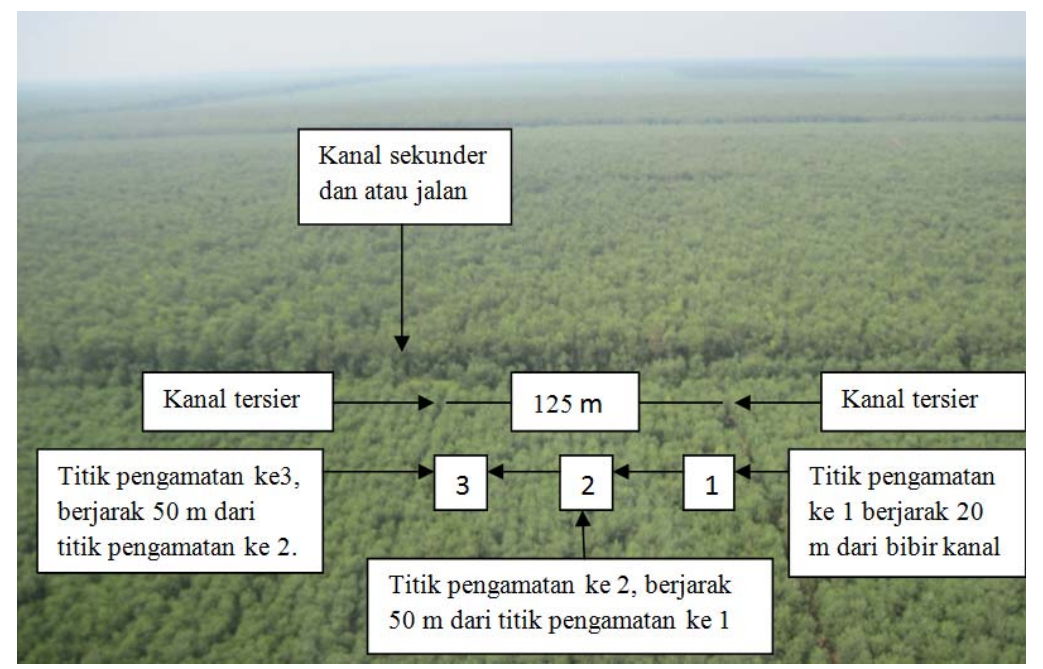

Gambar 1. Penempatan titik-titik pengamatan pada masing-masing plot penelitian.

\section{Pengambilan sampel tanah gambut.}

Pengambilan sampel dilakukan dengan menggunakan bor gambut Eidjel Kemp pada setiap selang kedalaman $50 \mathrm{~cm}$ sampai batas tanah mineral di bawah gambut. Setiap selang penambahan kedalaman $50 \mathrm{~cm}$ dilakukan pengambilan contoh tanah gambut, selanjutnya contoh tanah yang terambil dimasukkan ke dalam kantong plastik tebal dan diikat rapat-rapat untuk dianalisis nilai kadar seratnya. Pengambilan sampel tanah dilakukan pada 36 titik pengamatan.

\section{Pengukuran dinamika kedalaman muka air tanah.}

Pada masing-masing titik pengamatan pada lokasi terpilih, dipasang piezometer dari pipa paralon berdiameter 1 inchi panjang 1,5 m yang telah dilubangi (agar air tanah dari sekitar lubang masuk ke dalam pipa), kemudian pipa dibenamkan secara vertikal ke dalam tanah, dan kira-kira 0,25 m dari bagian atas pipa tersebut muncul di atas permukaan tanah untuk monitoring tinggi muka air tanah. Kedalaman muka air tanah diamati dengan cara memasukkan tongkat kayu ke dalam piezometer sampai mencapai permukaan air tanah (ditandai dengan basahnya bagian tongkat yang tercelup ke dalam air). Kemudian bagian tongkat kayu yang sejajar dengan permukaan tanah diberi tanda. Kedalaman muka air tanah ditentukan dengan cara mengukur panjang bagian tongkat yang kering di atas bagian yang basah sampai bagian tongkat yang sejajar dengan permukaan tanah. Piezometer dipasang pada 27 titik pengamatan dan diukur setiap bulan sekali selama 11 bulan (dari bulan Juli 2012 sampai dengan Mei 2013).

\section{Analisis data.}

Analisis dinamika kedalaman muka air tanah. Dinamika fluktuasi kedalaman muka air tanah dianalisis dengan menggunakan analisis regresi sederhana untuk melihat hubungan antara besarnya nilai kedalaman muka air tanah dengan curah hujan.

Analisis tingkat kematangan tanah gambut secara vertikal. Parameter yang diukur adalah tingkat kematangan gambut dengan melihat besarnya nilai kadar serat. Untuk mengetahui perbedaan konsentrasi kadar serat secara vertikal (berdasarkan perbedaan ketebalan gambut) dilakukan dengan analisis keragaman.

Analisis laju subsiden. Hubungan persamaan antara subsidence dengan rata-rata kedalaman muka air tanah pada hutan tanaman Acacia crassicarpa di lahan gambut dihitung dengan menggunakan rumus Hooijer (2012) sebagai berikut:

$\mathrm{S}=1,5-4,98 \times \mathrm{WD}$

Keterangan :

$\mathrm{S} \quad=$ Laju subsiden (cm/tahun)

WD = Rata-rata kedalaman muka air tanah di bawah permukaan gambut (-m; negatif)

\section{HASIL DAN PEMBAHASAN}

\section{Karakteristik Kedalaman Muka Air Tanah}

Dinamika kedalaman muka air tanah di lokasi penelitian dipengaruhi oleh kondisi curah hujan, seperti yang ditunjukkan dalam Gambar 2. Dari 27 titik pengamatan yang tersebar di lokasi penelitian menunjukkan kecenderungan yang sama bahwa pada bulan yang mempunyai curah hujan tinggi maka kedalaman muka air tanah semakin rendah atau mendekati permukaan tanah, begitu juga berlaku sebaliknya. Hal tersebut sejalan dengan hasil penelitian Andrie dkk (2010) yang menyebutkan bahwa dalam muka air tanah gambut pada musim kemarau letaknya jauh dari permukaan tanah, sedangkan pada musim hujan berada dekat permukaan tanah. 


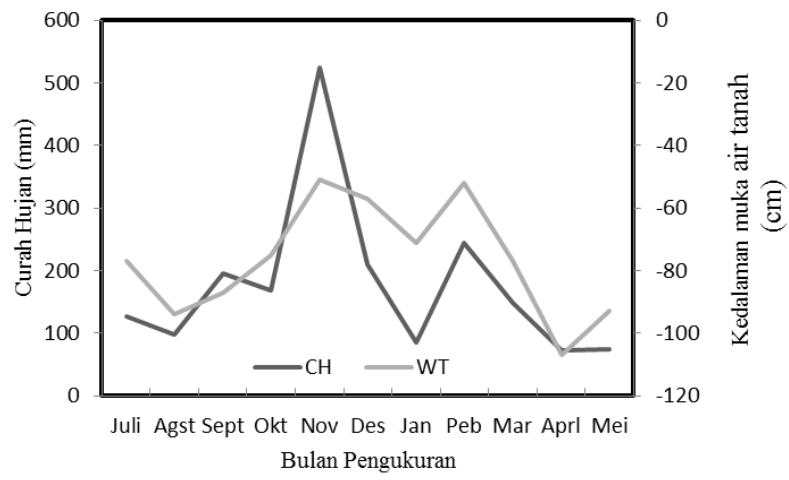

Gambar 2. Dinamika kedalaman muka air tanah pada lokasi penelitian.

Pada lokasi penelitian saat musim penghujan kedalaman muka air tanah dapat mencapai $10 \mathrm{~cm}$ dekat permukaan tanah, pada musim kemarau letaknya jauh dari permukaan tanah dapat mencapai $200 \mathrm{~cm}$ di bawah permukaan tanah. Selanjutnya menurut Rieley dkk (1997), pada musim hujan kedalaman muka air tanah di lahan gambut dapat mencapai $+0,5 \mathrm{~m}$ di atas permukaan tanah, tetapi pada musim kemarau dapat turun mencapai $-1,5 \mathrm{~m}$ di bawah permukaan tanah.

Selain dipengaruhi curah hujan, kedalaman muka air tanah gambut pada umumnya dipengaruhi oleh jarak dari bibir kanal, seperti yang dikemukakan oleh Andrie dkk (2010). Bahwa jarak dari saluran drainase akan mempengaruhi kedalaman muka air tanah gambut, yaitu semakin dekat dengan saluran drainase/kanal maka dalam muka air tanah letaknya jauh dari permukaan tanah dan semakin jauh dari saluran drainase dalam muka air tanah letaknya dekat dengan permukaan tanah. Pada lokasi penelitian, kanal tersier adalah yang berfungsi mengatur kedalaman muka air tanah di areal tegakan A. carsicarpa, jarak antar kanal tersier adalah $125 \mathrm{~m}$. Hasil pengamatan di lapangan selama 11 bulan menunjukkan bahwa pengaruh jarak dari kanal terhadap kedalaman muka air tanah gambut di bawah tegakan $A$. carsicarpa tidak berbeda nyata. Kondisi ini menunjukkan bahwa jarak antar kanal sebesar 125 m adalah merupakan jarak yang optimum untuk mengatur kedalaman muka air tanah di lapangan, sehingga tingkat perbedaan kedalaman muka air tanah menjadi tidak nyata.

\section{Kematangan Gambut}

Nilai rata-rata kadar serat yang menunjukkan tingkat kematangan gambut secara vertikal di bawah tegakan A. crassicarpa rotasi 3 umur 1, 2, 3, dan 4 tahun disajikan pada Tabel 1. Berdasarkan nilai rata-rata kandungan serat dan pengamatan lapangan terlihat bahwa tingkat kematangan gambut di daerah penelitian secara vertikal pada umumnya berkisar antara fibrik hingga saprik. Apabila dianalisis berdasarkan pengelompokkan umur maka pada lokasi di bawah tegakan $A$. crassicarpa umur 1, 2, dan 3 tahun menunjukkan bahwa profil tengah mempunyai tingkat kematangan yang didominasi oleh fibrik. Tingkat kematangan fibrik pada umumnya mempunyai stabilitas yang rendah, dan tingkat pelapukan yang masih mentah menunjukkan bahwa pada bagian tersebut kondisi airnya jenuh total sepanjang tahun. Kondisi tersebut menggambarkan daya dukung beban (bearing capacity) yang rendah dalam mendukung pertumbuhan tegakan A. crassicarpa, sehingga dalam pemanfaatannya perlu perhatian khusus terutama dalam hal pengaturan kedalaman muka air tanah dan tindakan silvikultur yang tepat agar tercapai produktivitas tegakan yang optimum.

Tabel 1. Nilai rata-rata kadar serat dan tingkat dekomposisi gambut pada berbagai ketebalan gambut dan umur tegakan A. crassicarpa.

\begin{tabular}{|c|c|c|c|c|}
\hline \multirow[t]{2}{*}{$\begin{array}{l}\text { Kedalaman gambut } \\
(\mathrm{cm})\end{array}$} & \multicolumn{4}{|c|}{$\begin{array}{c}\text { Rata-rata nilai kadar serat (\%) dan tingkat dekomposisi gambut } \\
\text { di bawah tegakan A. crassicarpa }\end{array}$} \\
\hline & 1 tahun & 2 tahun & 3 tahun & 4 tahun \\
\hline $0-50$ & 46,92 (Hemik) & 53,49 (Hemik) & 46,51 (Hemik) & 23,16 (Saprik) \\
\hline $50-100$ & 58,02 (Hemik) & 55,77 (Hemik) & 50,07 (Hemik) & 26,20 (Saprik) \\
\hline $100-150$ & 59,27 (Hemik) & 63,13 (Fibrik) & 64,92 (Fibrik) & 25,85 (Saprik) \\
\hline $150-200$ & 63,17 (Fibrik) & 68,53 (Fibrik) & 65,73 (Fibrik) & 32,84 (Saprik) \\
\hline $200-250$ & 66,28 (Fibrik) & 58,97 (Hemik) & 73,51 (Fibrik) & 46,55 (Hemik) \\
\hline $250-300$ & 64,19 (Fibrik) & 53,48 (Hemik) & 70,97 (Fibrik) & 43,23 (Hemik) \\
\hline $300-350$ & 58,76 (Hemik) & 54,48 (Hemik) & 65,10 (Fibrik) & 45,22 (Hemik) \\
\hline $350-400$ & 36,34 (Hemik) & & 67,48 (Fibrik) & 47,67 (Hemik) \\
\hline $400-450$ & & & & 32,00 (Saprik) \\
\hline $450-500$ & & & & 52,00 (Hemik) \\
\hline $500-550$ & & & & 48,00 (Hemik) \\
\hline $550-600$ & & & & 48,00 (Hemik) \\
\hline $600-650$ & & & & 52,00 (Hemik) \\
\hline $650-700$ & & & & 56,00 (Hemik) \\
\hline $700-750$ & & & & 64,00 (Fibrik) \\
\hline
\end{tabular}


Berdasarkan Tabel 1 juga terlihat bahwa pada tegakan umur 4 tahun, lapisan bawah tingkat kematangannya adalah fibrik. Kondisi tersebut sejalan dengan kedalaman gambut di lokasi tersebut yaitu di atas 7,5 m yang diduga merupakan kubah gambut Sungai Mandau sehingga kondisinya selalu jenuh air yang mengakibatkan proses pelapukan menjadi terhambat.

Berdasarkan hasil uji beda nyata data kadar serat pada profil tanah gambut dari seluruh titik pengamatan tanpa pengelompokkan umur tegakan A. crassicarpa maka nilai kadar serat/tingkat kematangan gambut secara signifikan dipengaruhi oleh kedalaman gambut. Pola nilai kadar serat berdasarkan kedalaman gambut di lokasi penelitian adalah pada kedalaman $0-150 \mathrm{~cm}$ rata-rata kadar serat tidak berbeda secara signifikan, rata-rata kadar serat meningkat sejak kedalaman gambut 150 - 350 cm dan kembali menurun setelah kedalaman 350 $\mathrm{cm}$.

Hal tersebut menunjukkan bahwa di lapisan atas tingkat kematangan gambut lebih matang, kemudian pada lapisan tengah lebih mentah dan pada lapisan bawah kembali lebih matang. Keragaan pola nilai kadar serat berdasarkan kedalaman gambut di lokasi penelitian disajikan pada Gambar 3.

Antara kedalaman 0-50 cm dengan kedalaman 150-350 cm menunjukkan perbedaan yang signifikan, pada kedalaman 0-50 cm nilai kadar serat menunjukkan nilai yang paling kecil. Dengan demikian tingkat kematangan pada kedalaman tersebut adalah yang paling matang dibandingkan dengan lapisan di bawahnya. Berdasarkan hal tersebut dapat diasumsikan bahwa dampak drainase terhadap tingkat kematangan gambut paling besar terjadi pada lapisan atas $(0-50 \mathrm{~cm})$.

Akibat keberadaan drainase maka pada lapisan di atas muka air tanah dari anaerob menjadi aerob sehingga proses dekomposisi berjalan lebih cepat pada lapisan tersebut. Hubungan antara kedalaman

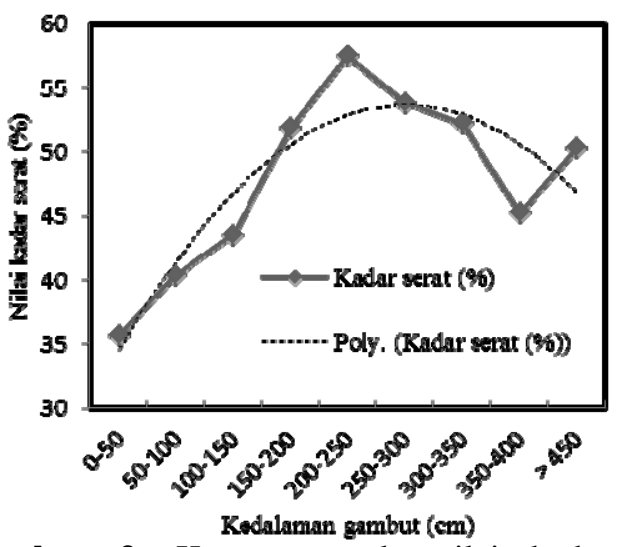

Gambar 3. Keragaan pola nilai kadar serat berdasarkan kedalaman gambut di lokasi HTI Acacia crassicarpa. muka air tanah dengan kematangan gambut di lokasi penelitian diketahui berkorelasi negatif, yaitu bahwa semakin dalam muka air tanah maka kandungan serat akan semakin rendah (gambut semakin matang) atau berlaku sebaliknya, walaupun hubungannya tidak kuat dengan nilai $(\mathrm{r}=$ 0,2 ). Penelitian serupa pernah dilakukan oleh Gandini (1998) yaitu dampak drainase pada tanah gambut di Berbak Jambi setelah 23 tahun dikelola untuk lahan pertanian. Dalam penelitiannya disebutkan bahwa setelah 23 tahun dikelola untuk lahan pertanian menyebabkan perubahan tingkat dekomposisi bahan organik dari fibrik dan hemik menjadi saprik yang diteliti pada lapisan gambut atas $(0-130 \mathrm{~cm})$.

Penelitian ini selain menganalisis tingkat kematangan gambut secara vertikal juga secara horizontal yaitu berdasarkan jarak dari bibir kanal. Nilai rata-rata kandungan serat tanah gambut berdasarkan jarak dari bibir kanal pada tegakan A. crassicarpa di Distrik Rasau Kuning disajikan pada Tabel 2. Walaupun ukuran kedalaman muka air tanah berpengaruh terhadap tingkat kematangan gambut, namun berdasarkan hasil uji beda nyata jarak pengukuran dari bibir kanal untuk seluruh titik pengamatan tidak berpengaruh secara nyata terhadap tingkat kematangan gambut.

Tingkat kematangan gambut umumnya berkorelasi dengan pola penggunaan lahan saat ini. Pada lokasi yang sudah dibuka seperti untuk HTI tingkat kematangan di lapisan atas pada umumnya hemik/saprik, sedangkan pada lahan yang masih alami seperti di lokasi Suaka Margasatwa Danau Pulau Besar tingkat kematangan lapisan atas pada umumnya antara fibrik/hemik. Berdasarkan hasil analisis perbandingan nilai kadar serat antara lahan gambut alami dengan HTI seperti yang ditunjukkan pada Tabel 3, bahwa secara umum di lokasi hutan gambut alami nilai kadar serat lebih besar dibandingkan dengan di lokasi HTI, untuk kedalaman 0 - 150 nilai kadar serat gambut pada

Tabel 2. Nilai rata-rata kandungan kadar serat tanah gambut berdasarkan jarak dari bibir kanal pada tegakan A. crassicarpa di Distrik Rasau Kuning

\begin{tabular}{ccc}
\hline \multicolumn{3}{c}{ Kandungan kadar serat gambut (\%) } \\
\hline Jarak 20 (m) & Jarak 70 (m) & Jarak 120 (m) \\
\hline 45,74 & 62,66 & 63,53 \\
68,74 & 59,27 & 52,86 \\
67,41 & 54,54 & 59,75 \\
52,13 & 54,00 & 62,75 \\
66,53 & 57,51 & 28,13 \\
26,93 & 30,53 & 38,00 \\
38,5 & 41,87 & 34,33 \\
34,74 & 30,93 & 38,95 \\
27,78 & 32,74 & 34,19 \\
\hline
\end{tabular}


Tabel 3. Selisih rata-rata perbedaan nilai kadar serat (\%) antara hutan gambut alami dengan HTI.

\begin{tabular}{cccc}
\hline Kedalaman gambut $(\mathrm{cm})$ & Selisih rata-rata perbedaan kadar serat (\%) & P-value & Keterangan \\
\hline $0-50$ & 18,8 & 0,014 & $\mathrm{H}_{0}$ ditolak \\
$0-100$ & 18,4 & 0,003 & $\mathrm{H}_{0}$ ditolak \\
$100-150$ & 17,5 & 0,001 & $\mathrm{H}_{0}$ ditolak \\
$150-200$ & 5,5 & 0,615 & $\mathrm{H}_{0}$ diterima \\
$200-250$ & 0,9 & 0,919 & $\mathrm{H}_{0}$ diterima \\
$250-300$ & 1,8 & 0,838 & $\mathrm{H}_{0}$ diterima \\
$300-350$ & $-0,2$ & 0,979 & $\mathrm{H}_{0}$ diterima \\
$350-400$ & 10,9 & 0,313 & $\mathrm{H}_{0}$ diterima \\
$400-500$ & 13,5 & 0,067 & $\mathrm{H}_{0}$ diterima \\
$>500$ & $-3,2$ & 0,462 & $\mathrm{H}_{0}$ diterima \\
\hline
\end{tabular}

Tabel 4. Laju penurunan permukaan gambut berdasarkan rata-rata kedalaman muka air tanah pada tegakan A. crassicarpa rotasi 3 umur 1, 2 dan 3 tahun di Distrik Rasau Kuning, periode Juli 2012 - Mei 2013.

\begin{tabular}{cccc}
\hline $\begin{array}{c}\text { Umur tegakan } \\
\text { (tahun) }\end{array}$ & $\begin{array}{c}\text { Jarak pengukuran } \\
\text { dari bibir kanal }(\mathrm{m})\end{array}$ & $\begin{array}{c}\text { Rata-rata kedalaman muka air } \\
\text { tanah gambut (-cm) }\end{array}$ & $\begin{array}{c}\text { Laju subsiden per } \\
\text { tahun }(\mathrm{cm} / \text { tahun })\end{array}$ \\
\hline 1 & 20 & -69 & 4,9 \\
1 & 70 & -60 & 4,5 \\
1 & 120 & -67 & 4,8 \\
2 & 20 & -65 & 4,7 \\
2 & 70 & -80 & 5,5 \\
2 & 120 & -72 & 5,1 \\
3 & 20 & -75 & 5,2 \\
3 & 70 & -90 & 6,0 \\
3 & 120 & -104 & 8,5 \\
\hline Rata-rata & & 5,5 \\
\hline
\end{tabular}

kondisi alami berbeda secara signifikan dengan di HTI. Kondisi tersebut dimungkinkan karena pada gambut alami kedalaman muka air tanah pada musim kemarau berkisar antara $15-25 \mathrm{~cm}$ di bawah permukaan tanah sedangkan pada musim hujan pada umumnya tergenang, sehingga tanah gambut tetap lembab dan basah sehingga proses dekomposisi menjadi lebih lambat dibandingkan dengan tanah gambut yang sudah didrainase. Berdasarkan uraian tersebut dapat untuk ditunjukkan bahwa drainase berpengaruh secara signifikan terhadap tingkat kematangan gambut terutama pada lapisan di atas permukaan air tanah.

\section{Laju Penurunan Permukaan Gambut}

Subsiden adalah proses penurunan permukaan gambut yang telah direklamasi atau didrainase, karena pertukaran suasana gambut dari anaerob ke aerob. Menurut Limin dkk (2000) bahwa pembuatan saluran drainase akan menyebabkan air keluar dari gambut kemudian oksigen masuk ke dalam bahan organik dan meningkatkan aktivitas organisme, yang selanjutnya akan mengakibatkan terjadinya proses dekomposisi jauh lebih cepat dan biomassa gambut akan berkurang dan mengalami penyusutan sehingga permukaan gambut mengalami penurunan. Rata-rata laju penurunan permukaan tanah (subsidence) di lokasi penelitian yang dihitung berdasarkan kedalaman muka air tanah gambut bervariasi antara 4,9-8,5 cm/tahun dengan rata-rata sebesar $5,5 \mathrm{~cm} /$ tahun. Laju penurunan permukaan gambut berdasarkan tinggi muka air tanah pada tegakan A. crassicarpa rotasi 3 umur 1, 2, dan 3 tahun di Distrik Rasau Kuning pada periode Juli 2012 - Mei 2013 disajikan pada Tabel 4.

Nilai rata-rata laju subsiden yang dihasilkan pada penelitian ini lebih tinggi dibandingkan dengan nilai yang dipantau melalui pembacaan patok ukur yang dilakukan oleh PT. AA. Nilai laju subsidensi gambut di areal PT. AA yang dipantau melalui pembacaan patok ukur yang dipasang di Distrik Rasau Kuning, pada Agustus 2007 sebesar 8,0 cm/tahun, Juli 2009 3,5 cm/tahun dan Juli 2010 sebesar 3,0 cm/tahun. Hooijer dkk (2012) menyebutkan bahwa laju subsiden yang terjadi pada tanaman akasia dan kelapa sawit di Asia Tenggara pada 5 tahun pertama setelah drainase adalah sebesar $142 \mathrm{~cm}, 75 \mathrm{~cm}$ terjadi di tahun pertama. Setelah 5 tahun laju subsiden pada kedua jenis tanaman tersebut adalah konstan sekitar 5 $\mathrm{cm} /$ tahun pada rata-rata kedalaman muka air tanah 0,7 m. Dari nilai tersebut terlihat bahwa laju subsiden cenderung menurun, hal ini terjadi karena laju subsiden berkorelasi negatif dengan tingkat kematangan gambut, semakin matang gambut maka laju subsiden akan semakin rendah karena gambut yang lebih matang memiliki bobot isi yang lebih besar dan struktur gambut yang lebih padat sehingga subsiden yang terjadi semakin berkurang. Secara umum subsiden terjadi lebih cepat pada lokasi yang dekat dengan saluran drainase 
dibandingkan dengan yang lebih jauh (Neil dkk, 2005; Frizdew, 2012). Kebalikan dengan kajian sebelumnya bahwa laju subsiden di lokasi penelitian berbanding lurus dengan jarak dari saluran drainase, semakin jauh dari saluran drainase maka laju subsiden juga semakin besar, seperti yang ditunjukkan pada Gambar 4.

Kondisi tersebut disebabkan adanya dua saluran drainase yang sejajar yaitu jarak antara kanal tersier yang satu dengan lainnya hanya berjarak 125 m. Diperkirakan saluran drainase yang dekat dengan jalan tempat awal peletakan titik transek banyak mengalami pendangkalan karena sudah tidak adanya pemeliharaan kanal dan juga karena lebih terdampak oleh aktivitas manusia karena dekat dengan jalan. Untuk saluran yang berada lebih dalam masih berfungsi dengan baik sehingga pergerakan air lebih besar ke arah saluran drainase yang lebih dalam dibandingkan dengan yang dekat jalan.

Laju penurunan permukaan gambut juga dipengaruhi oleh umur saluran drainase, seperti yang ditunjukkan pada penelitian Maswar (2011) bahwa laju penurunan permukaan tanah gambut untuk penggunaan lahan hutan adalah sebesar 3,8 $\mathrm{cm} / 14$ bulan pada umur saluran drainase 2 tahun dengan kedalaman muka air tanah maksimal 69,8 $\mathrm{cm}$. Pada kajian di lokasi penelitian umur saluran drainase diperkirakan 15 tahun dengan kedalaman muka air tanah maksimal $175 \mathrm{~cm}$, dengan rata-rata laju penurunan permukaan tanah gambut sebesar $5,5 \mathrm{~cm} /$ tahun. Nilai ini lebih tinggi dibandingkan dengan yang dilakukan oleh Maswar (2011). Hal ini diduga karena pada lokasi penelitian pada profil tengah tanah gambut banyak didominasi oleh tingkat kematangan fibrik yang lebih cepat terjadi penyusutan akibat dilakukan drainase apalagi saluran drainase tidak dipelihara setelah tanaman berumur 1 tahun sehingga kedalaman muka air tanah tidak dapat dipertahankan pada kedalaman yang optimum $(80 \mathrm{~cm})$. Apabila dibandingkan dengan penggunaan lahan untuk kelapa sawit pada umur saluran 2 tahun dengan kedalaman muka air tanah sebesar $65,4 \mathrm{~cm}$ laju subsiden yang terjadi sebesar 8,2 /14 bulan. Untuk semak umur saluran 2 tahun maksimum kedalaman muka air tanah 83,2 cm laju subsiden yang terjadi sebesar 8,6 /14 bulan. Untuk kelapa sawit dengan umur saluran drainase 15 tahun dengan kedalaman muka air maksimalnya 58,0 cm mempunyai laju subsiden sebesar 4,8/14 bulan, nilai ini lebih kecil dibandingkan pada lokasi penelitian. Hal ini menunjukkan bahwa perlunya pengendalian kedalaman muka air tanah untuk mencegah laju subsiden yang lebih cepat sehingga tanah gambut dapat dipergunakan dalam jangka waktu yang lama.

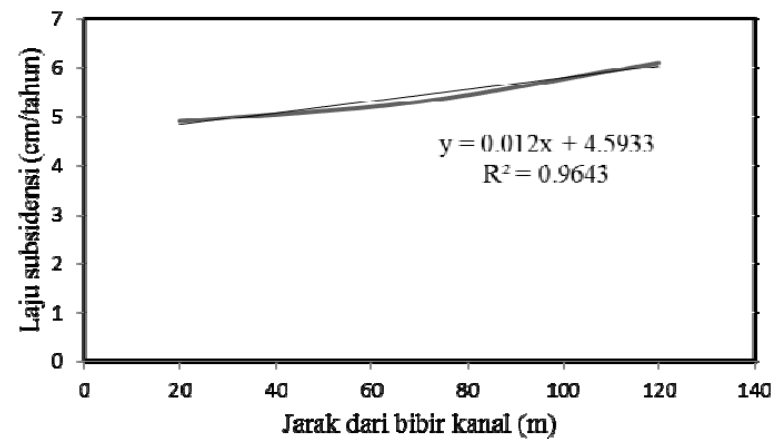

Gambar 4. Hubungan antara jarak dari saluran drainase dengan besarnya laju subsiden pada lokasi penelitian.

Laju subsiden dapat digunakan untuk memperkirakan umur produktivitas lahan gambut tersebut. Apabila rata-rata kedalaman gambut di lokasi penelitian adalah $3,23 \mathrm{~m}$ dengan laju subsiden 5,5/tahun konstan dan tidak ada faktor lain yang mempengaruhi, maka diperkirakan gambut di lokasi penelitian akan habis setelah 58,7 tahun mendatang. Namun pada dasarnya nilai tersebut adalah tidak mutlak seperti yang dikemukakan oleh Stewart (1991); Salmah dkk (1994); dan Wösten dkk (1997) yaitu bahwa laju atau kecepatan subsiden adalah tidak konstan dan berbeda-beda pada setiap lokasi tergantung pada banyak faktor, antara lain tingkat kematangan gambut, tipe gambut, kecepatan dekomposisi, kepadatan dan ketebalan gambut, kedalaman drainase, iklim, serta penggunaan lahan dan faktor kebakaran lahan.

\section{KESIMPULAN}

Dinamika kedalaman muka air tanah di lokasi penelitian dipengaruhi oleh curah hujan, yaitu pada bulan-bulan dengan tingkat curah hujan tinggi, ratarata kedalaman muka air tanah dangkal, sedangkan pada bulan-bulan dengan curah hujan rendah, ratarata kedalaman muka air tanah menjadi sangat dalam. Fluktuasi kedalaman muka air tanah gambut yang besar, akan memberikan dampak terhadap tingkat kematangan tanah gambut dan laju penurunan tanah gambut (subsiden). Pengaruh drainase terhadap tingkat kematangan gambut mempengaruhi tingkat kematangan gambut sampai pada batas kedalaman muka air tanah, dan berdampak pada laju penurunan tanah gambut sebesar $5,5 \mathrm{~cm} /$ tahun.

\section{DAFTAR PUSTAKA}

Andrie, E., 2010. The Dept of Ground Water Table Dynamics and Characteristic of Peatland Near Drainage Canal ex, Mega Rice Project in Central-Kalimantan. Makalah Seminar Ilmiah 
VI Lingkungan Tropis-Ikatan Ahli Teknik Penyehatan dan Tehnik Lingkungan Indonesia (IATPI). Denpasar, 29 Juli 2010.

Anonim. 2009. Petunjuk Teknis Analisis Kimia Tanah, Tanaman, Air dan Pupuk. Edisi ke 2. Balai Penelitian Tanah. Bogor.

Frizdew, R., 2012. Variasi Kadar Karbon Organik Berdasarkan Perbedaan Kedalaman Muka Air Pada Lahan Gambut yang Diusahakan Untuk Komoditas Perkebunan. Thesis. Sekolah Pascasarjana. Institut Pertanian Bogor. Bogor.

Gandini, T., 1998. Perubahan Sifat dan Klasifikasi Tanah Gambut setelah 23 Tahun Penggunaan Lahan untuk Pertanian di Delta Berbak Jambi. Disertasi. Sekolah Pascasarjana. IPB. Bogor.

Hooijer, A., Silvius, M., Wosten, H., dan Page, S., 2006. Peat- $\mathrm{CO}_{2}$. Assessment of $\mathrm{CO}_{2}$ Emissions From Drained Peatlands in SE Asia. Delf Hydraulics Report, Q3943.

Hooijer, A., Page, S., Jauhiainen, J., Lee, W.A., Idris, A., dan Anshari, G., 2012. Subsidence and Carbon Loss in Drained Tropical Peatlands, Biogeosciences 9:1053-1071.

Limin, S., Layuniati, dan Jamal, Y., 2000. Utilization of Inland Peat for Food Crop Commodity Development Requires High Input and is Detrimental to Peat Swamp Forest Ecosystem. Proc. International Symposium on Tropical Peatlands 22-23 November 1999. Bogor.

Marolop, R., Widodo, A., Ismail dan Setyawan, A. 2007. Pengelolaan Lahan Gambut untuk Pengembangan Hutan Tanaman Industri PT. Arara Abadi, Riau. Makalah Sosialisasi Kegiatan BPHPS Guna Mendukung Kebutuhan Riset Hutan Tanaman Kayu Pulp, 27 November 2007. Balai Penelitian Hutan Penghasil Serat. Pekanbaru.

Maswar., 2011. Kajian Cadangan Karbon Pada Lahan Gambut Tropika Yang Didrainase Untuk Tanaman Tahunan. Disertasi. Program Studi Ilmu Tanah, Sekolah Pascasarjana, Institut Pertanian Bogor. Bogor.

Neil, F., Sarah, B., dan Malcolm, Mc.L. 2005. Peat Subsidence near Drains in the Waikato Region. Environment Waikato Technical Report 2005/40.

Rahmadi., 2009. Effects of Climate Change and Land Subsidence on Water Management zoning in Tidal Lowlands Case Study Telang, South Sumatra. Thesis. UNESCO - IHE Delft.

Rieley, J.O., Page, S.E., Limin, S.H., and Winiarti S., 1997. The Peatland Resources of Indonesia and the Kalimantan Peat Swamp Forest Research Project. Proc. Int'l. Symp. Biodiversity, Environmental Importance and Sustainability of Tropical Peat and Peatland. Samara Publ.

Saefudin, A., 2009. North EasLand and Water Evaluation of Lowland Areas Case Study : Lowlands intern Muara Enim Region Indonesia. Thesis. UNESCO - IHE, Delft.

Salmah, A.Z., Aminuddin, Y., Marzuki, H., dan Azizah, M.J., 1994. The Magnitude of Problems with The Sustainable Development of Coastal Plains in Malaysia: Research Needs and Related Priorities. Papers on the Regional Workshop on the Sustainable Use of Coastal Land in'South-East Asia. AIT, Bangkok, Thailand.

Stewart, J.M., 1991. Subsidence in Cultivated Peat Lands. in Tropical Peat. Proceedings of the International Symposium on Tropical Peatland. 6-10 May 1991 Kuching.

Suhartana, S., Yuniawati dan Dulsalam, 2013ª . Biaya dan Produktivitas Penyaradan dan Pembuatan/Pemeliharaan Kanal di HTI rawa gambut di Riau dan Jambi. Jurnal Penelitian Hasil Hutan 31(1):36-48.

Suhartana, S., Yuniawati dan Dulsalam, 2013 . Optimasi petak tebang di Hutan Tanaman Rawa Gambut Berdasarkan Produktivitas dan Biaya Terkait. Jurnal Penelitian Hasil Hutan 31(3):200-212.

Suhartana, S., Yuniawati dan Dulsalam. 2014. Luas Petak Tebang Optimal Pemanenan Kayu di Areal Hutan Tanaman Rawa Gambut. Jurnal Penelitian Hasil Hutan, 32(3):175-188.

Wahyunto., Ritung, S., Suparto., dan Subagjo, H., 2005. Sebaran Gambut dan Kandungan Karbon di Sumatera dan Kalimantan. Proyek Climate Change, Forests and Peatlands in Indonesia. Wetlands International - Indonesia Programme dan Wildlife Habitat Canada. Bogor.

Wösten, J.H.M., Ismail, A.B., dan Van Wijk, A.L.M., 1997. Peat Subsidence and Its Practical Implications: a Case Study in Malaysia. Geoderma, 78:25-36. 